\section{Are publishers doing their job?}

SIR - You ask "who will write more books?" (Nature 294, 17; 1981). Here is one depressing answer. With the four books I have published (in 1951, 1968, 1971 and 1982) I encountered no real difficulties in having them accepted for publication. Since then, however, my attempts to interest scientific publishers in further review material have run into every imaginable difficulty.

The first of these books (Mosquito Behaviour and Ecology: Reviews of Progress) was submitted to a UK publisher who had expressed interest in the outlined proposal. There were long delays in obtaining comments from the referees I had been asked to nominate and even though these were favourable, the publishers decided - five months after submission of the manuscript - to reject the idea on the grounds of "marketability",

The manuscript was then submitted to another UK publisher who had reacted encouragingly to the outline. Here again there were long delays in obtaining comments from referees so that after five months I withdrew the manuscript. By this time a US publisher had expressed interest in the project, and agreed last November to publish the book.

This might appear to be a happy ending, but a final obstacle has arisen which has proved insuperable. The large numbers of charts and figures, carefully and painstakingly re-drawn at the publishers request to standards which have been acceptable in the past, have been rejected as not being in "camera-ready", condition. The publishers advise that these should be redone by a professional artist, presumably at my expense. As there is no way in which I can pay for such an expensive and unforeseen item, the contract has been cancelled by the publishers.

In the case of a second proposed book (Pesticide Impact on Stream Macroinvertebrates), the idea has proved acceptable to a continental publisher but this acceptance carries a sting in the tail in that the manuscript must be submitted in "camera-ready" form for photo-offset reproduction. It would be almost impossible for a single author without secretarial help and proper equipment to comply with these requirements. The alternative proposed by the publishers is for them to process the manuscript into a camera-ready condition, and then to debit me to the extent of royalties on the first 1,000 copies

The effect of all these processes is that anything up to a year may elapse between completion of a manuscript and its final acceptance by a publisher, with a further period of anything up to two years before publication. Not only is the author virtually working for nothing during this period, but these delays make nonsense of any hope, or claim, that a review deals adequately with "recent advances"'. This time lapse is particularly ironical when photocopying facilities could make available copies of reviews within weeks of completion.

These events throw a great deal of light on the query - or the plea - "who will write more books?"'. The combined result of all these obstacles, delays and demands is effectively to gag the communication of material which can justly claim to provide the "scholarly reviews in the scientific literature" required.

Ascot, Berks, UK R.C. MUIRHEAD-THOMSON

\section{Animal sexing patents}

SIR - The news item "Techniques for sexing embryos now possible" " was interesting but the statement "Hitherto, the sex of a calf fetus could not be known until birth "' should be corrected. In fact, the first calf to have its sex diagnosed as an embryo was born on Christmas day, 1975. That heifer had had a very small piece of trophoblast removed by microdissection before transfer about 2 weeks after fertilization and the sex of the tissue had been determined by chromosomal analysis without harming the calf which develops from the embryonic disk ${ }^{2}$. Since then, calves have even been born from embryos sexed by chromosomal analysis of a few cells aspirated from morula stage embryos still within the zona pellucida ${ }^{3}$ and, more recently, from morulae which have been microsurgically bisected ${ }^{4}$, allowing one half to be transferred while the other is cytogenetically sexed. Many of these developments have been recently reviewed $^{5}$.

The major advance stemming from the work of Genetic Engineering Inc. is the possibility of sexing embryos at an age when they can still be successfully frozen. It seems, though, regrettable and ironic that such important findings were, because of patent applications, reported without scientific detail or discussion during the same week that over 600 members of the International Embryo Transfer Society were meeting within a few miles of Denver.

\section{W.C.D. HARE \\ Animal Diseases Research Institute, Nepean, Ontario, Canada}

K.J. BETTERIDGE

Centre de Recherche en Reproduction Animale,

Université de Montréal,

Quebec, Canada

Shapley, D. Nature 301, 101 (1983).

2. Hare, W.C.D., Mitchell, D., Betteridge, K.J., Eaglesome, M.D. \& Randall, G.C.B. Theriogenology 5, 243-253 (1976).

3. Moustafa, L.A., Hahn, J., \& Roselius, R. Berl. .Muench. Tieraerztl. Wochenschr, 91, 236-238 (1978).

Williams, T.J., Elsden, R.P. \& Seidel, G.E. Jr Theriogenology 17, 114 (1982).

5. Betteridge, K.J., Hare, W.C.D. \& Singh, E.L. in New Technologies in Animal Breeding (eds Brackett, B.G.,
Seidel, G.E. Jr. \& Seidel, S.M.) 109-125 (Academic, New York, 1982).

\section{A weighty issue}

SIR - Your leading article on lead in petrol (Nature 21 April, p.641) is both illinformed and contradictory. You embrace the conclusions of the Royal Commission on Environmental Pollution', but then go out of your way to discredit groups such as CLEAR which gave evidence to the Royal Commission and whose public activities ensured that the government responded quickly to the recommendations made in the report. What you fail to realize is that many of the points made by the commission are precisely those that CLEAR has argued for in the past fifteen months.

Thus, we have always accepted that lead pollution is a multi-source problem, but we have also argued that "the largest single controllable source of lead for the population as a whole is lead in petrol" (see paragraph 7.2 in the report).

We accepted that evidence of lead's harmful effects in the general population may not be conclusive, but levels typically found in the population today are very close to levels known to be toxic (see 5.23).

We accepted that the contribution of lead in petrol to lead in dust and to lead in food may be difficult to quantify precisely, but since lead is a cumulative poison, we argued that it cannot make sense to allow environmental burdens to go on increasing indefinitely (see 1.6).

Finally, the edited proceedings of the CLEAR symposium ${ }^{2}$ were submitted to the Royal Commission in their entirety. If the writer of your leading article is able to identify any statement in those proceedings which is either "dishonest" or a "shameless exaggeration" of the evidence, then I would be interested to learn of it.

R. RUSSEl.I. JONES

The Campaign for Lead-free Air,

London NI, UK

1. Royal Commission on Environmental Pollution. Ninth Report, Lead in the environment (HMSO, London, 1983). 2. Lead versus Heaith, Sources and Effects of Low Level Lead Exposure (cds. Rutter, M. \& Russcll Jones, R.) (Wilcy. Chichester. 1983)

\section{Oxbridge entrance}

SIR - In editing my note on "Who goes to Oxbridge?"' (Nature 26 May, p.278) a confusion was introduced. The figure of 14.6 per cent of the 1,068 maintained school candidates (men + women) placed in Class I in their final examinations at Cambridge last year was to be compared not with " 10.9 per cent of firsts for the independent school girls" but with 10.9 per cent of the 862 candidates of both sexes from the independent schools. That percentage was somewhat depressed by the disappointing 4.4 per cent of firsts for independent school girls, as compared with 8.8 per cent for girls from maintained schools, the difference between male candidates from the maintained and independent sectors being considerably less than that. C.B. GOODHART Gonville and Caius College, Cambridge, UK 